\title{
ANALISIS KINERJA PENYULUH PERTANIAN BERDASARKAN PERSEPSI KELOMPOK TANI DI KELURAHAN TARATARA SATU KECAMATAN TOMOHON BARAT KOTA TOMOHON
}

\author{
Sandy Alfa Stefano Sambouw \\ Elsje Pauline Manginsela \\ Jane Sulinda Tambas
}

Naskah diterima melalui Email agrisosioekonomi@unsrat.ac.id

: Sabtu, 17 Oktober 2020

Disetujui diterbitkan

: Selasa, 27 Oktober 2020

\begin{abstract}
This study aims to describe how the performance of agricultural instructors based on the perceptions of farmer groups in Taratara Satu Village, West Tomohon District, Tomohon City. The research was conducted from February to April 2020. The data used are primary and secondary data. Primary data were obtained through direct interviews with 18 respondents using a questionnaire and secondary data were obtained from the government office of the Taratara Satu village. The sampling method used purposive sampling method. The research results showed, 74 percent of farmers said that the extension workers had carried out their functions well, while 26 percent said that the extension workers were lacking in carrying out their roles and functions.
\end{abstract}

Keywords : extension, perception, farmer groups, agricultural extension performance.

\begin{abstract}
ABSTRAK
Penelitian ini bertujuan untuk mendeskripsikan bagaimana kinerja penyuluh pertanian berdasarkan persepsi kelompok tani di Kelurahan Taratara Satu Kecamatan Tomohon Barat Kota Tomohon. Penelitian dilaksanakan pada bulan February sampai bulan April 2020. Data yang digunakan adalah data primer dan sekunder. Data primer diperoleh melalui wawancara langsung kepada 18 responden menggunakan kuesioner dan data sekunder diperoleh dari kantor pemerintah kelurahan Taratara satu. Pengambilan sampel dilakukan secara sengaja (purposive sampling). Hasil penelitian menunjukkan bahwa 74 persen petani mengatakan penyuluh sudah menjalankan fungsinya dengan baik, sedangkan 26 persen mengatakan penyuluh kurang dalam melaksanakan peran dan fungsinya.
\end{abstract}

Kata kunci : penyuluhan, persepsi, kelompok tani, kinerja penyuluh pertanian. 


\section{PENDAHULUAN}

\section{Latar Belakang}

Pertanian merupakan salah satu sektor utama yang menopang kehidupan masyarakat, karena sektor pertanian merupakan mata pencaharian sebagian besar penduduk Indonesia. Selain itu juga, sektor pertanian menjadi salah satu pilar dalam menggerakkan perekonomian Nasional (Tinaprilla, 2014). Petani adalah pelaku utama, baik sebagai pengelola maupun pelaksana dalam kegiatan produksi pertanian serta merupakan bagian dari masyarakat Indonesia yang perlu ditingkatkan kesejahteraan dan kecerdasannya. Salah satu upaya peningkatan kecerdasan dan kesejahteraan tersebut dilaksanakan melalui kegiatan penyuluhan. Dengan adanya penyuluhan diharapkan semua perkembangan informasi pertanian dapat diteruskan pada petani. Semakin banyak informasi yang diterima dan dimanfaatkan oleh petani maka semakin efektif penyuluh tersebut (Hasan, 2016).

Penyuluhan bertujuan meningkatkan aspek pengetahuan (kognitif), sikap mental (afektif), dan keterampilan (psikomotorik) dari para petani. Penyuluhan sebagai proses bimbingan dan pendidikan non-formal bagi petani memiliki peran yang sangat penting dalam mencapai tujuan pembangunan di sektor pertanian. Kegiatan penyuluhan tidak hanya sebuah proses penyampaian informasi, tetapi juga sebagai sarana konsultasi, pelatihan, dan aktivitas lain yang dapat mengubah perilaku para petani agar lebih adoptif terhadap teknologi baru. Dan juga agar petani berwawasan luas, berkemampuan dalam pengambilan keputusan dengan cepat, mampu menyaring kebenaran informasi, memilih kebijakan yang sesuai dengan kondisi dan potensi masing-masing dan mengimplementasikannya pada usaha taninya (Tinaprilla, 2014).

Kecamatan Tomohon Barat adalah salah satu kecamatan yang ada di Kota Tomohon yang memiliki delapan kelurahan. Jumlah penyuluh pertanian di Kecamatan Tomohon Barat berjumlah delapan dan masing-masing memegang satu Kelurahan. Kelurahan Taratara Satu adalah salah satu Kelurahan yang berada di Kecamatan Tomohon Barat yang memiliki 16 kelompok tani. Luas wilayah pertanian di Kelurahan Taratara Satu sebesar 325 ha yang terdiri atas 200 ha lahan persawahan dan 125 ha lahan perkebunan. Sebanyak 20\% masyarakat di Taratara Satu adalah sebagai petani. Sebagian besar petani merupakan petani padi sawah. Terdapat enam kelompok Tani padi sawah yang ada di Kelurahan Taratara Satu yaitu: Kelompok Tani Imanuel, Kelompok Tani Aga Kayutombal, Kelompok Tani Amian, Kelompok Tani Maju Bersama, Kelompok Tani Rewo, Kelompok Tani Pinangsungkulan. Jumlah anggota setiap Kelompok Tani masing-masing 20 sampai 25 anggota. Kinerja penyuluh adalah hasil yang di capai dari apa yang menjadi tugas dan tanggung jawab sebagai penyuluh. Adapun indikator kinerja penyuluh pertanian yaitu kunjungan ke wilayah yang menjadi binaan penyuluh, program kerja yang dibuat, pelaporan yang dilakukan dari setiap kegiatan yang dilakukan, kedisiplinan penyuluh dalam menjalankan tugas dan tanggung jawabnya sebagai penyuluh, materi penyuluhan serta metode yang digunakan penyuluh dalam melakukan kegian penyuluhan. (Animar. 2013)

Penyuluh perlu berperan aktif untuk membimbing, mendidik serta memfasilitasi kelompok tani sesuai dengan tugas dan fungsinya sebagai penyuluh pertanian. Oleh sebab itu penelitian ini ingin mengetahui apakah satu penyuluh dapat membimbing kelompok-kelompok tani yang ada di Kelurahan Taratara Satu dengan baik dan bagaimana kinerja penyuluh pertanian berdasarkan persepsi kelompok tani di Kelurahan Taratara Satu Kecamatan Tomohon Barat Kota Tomohon.

\section{Penyuluhan Pertanian}

Istilah penyuluhan, dalam bahasa Indonesia, berasal dari kata dasar "suluh" yang berarti pemberi terang di tengah kegelapan. Namun penerangan yang dilakukan tidaklah sekadar "memberikan penerangan" tetapi penerangan yang diberikan selama penyuluhan harus terus menerus dilakukan sampai betulbetul diyakini bahwa segala sesuatu yang diterangkan benar-benar telah dipahami, dihayati, dan dilaksanakan oleh masyarakat sasarannya. Dalam kaitan ini tujuan atau sasaran yang sebenarnya dari penyuluhan adalah terjadinya perubahan perilaku. Hal ini merupakan perwujudan perubahan dalam hal pengetahuan, sikap, dan keterampilan yang dapat diamati secara langsung maupun tidak langsung dengan indera manusia (Mardikanto, 2009). 


\section{Kinerja Penyuluh Pertanian}

Menurut Jahi (2006) bahwa Kinerja seorang penyuluh dapat dilihat dari dua sudut pandang yaitu:

1. kinerja merupakan fungsi dari karakteristik individu dan merupakan variabel penting yang dipengaruhi perilaku seseorang termasuk penyuluh pertanian;

2. kinerja penyuluh pertanian merupakan pengaruh dari situasional dalam terjadinya perbedaan pengelolaan dan penyelenggaraan penyuluhan pertanian di setiap daerah atau kabupaten yang menyangkut beragamnya aspek kelembagaan, ketenagaan, program penyelengaraan dan pembiayaan.

Kinerja merupakan fungsi dari karakteristik penyuluh pertanian dalam menjalankan peran tersebut, penyuluh mempunyai tugas pokok dan fungsi yang menjadi acuan dalam melakukan penyuluhan sebagai salah satu fungsi penyuluh dalam pemberdayaan masyarakat.

\section{Pengertian Persepsi}

Persepsi merupakan suatu proses yang didahului oleh proses penginderaan yaitu merupakan proses diterimanya stimulasi oleh individu melalui alat indera atau juga disebut proses sensorik. Namun proses itu tidak berhenti begitu saja melainkan stimulasi tersebut diteruskan dan proses selanjutnya merupakan proses persepsi. Persepsi adalah proses yang menyangkut masuknya pesan atau informasi kedalam otak manusia, melalui persepsi manusia terus-menerus mengadakan hubungan dengan lingkungannya. Hubungan ini dilakukan dengan inderanya, yaitu indera penglihat, pendengar, peraba, perasa dan pencium. Persepsi adalah cara pandang seseorang terhadap apa yang dilihat, dirasakan dan didengar (Slameto, 2010).

\section{Faktor-faktor yang Mempengaruhi Persepsi Petani Terhadap Kinerja Penyuluhan}

Menurut Gomes (2001), ada beberapa faktor yang dapat mempengaruhi persepsi petani terhadap kinerja penyuluh pertanian yaitu sebagai berikut:

a. Quantity of work e. Cooperation

b. Quality of work f. Dependability

c. Job knowledge g. Initiative

d. Creativeness h. Personal qualities

\section{Kelompok Tani}

Kelompok tani merupakan kelembagaan tani yang langsung mengorganisir para petani dalam mengembangkan usaha taninya. Kelompok tani merupakan organisasi yang dapat dikatakan berfungsi dan ada secara nyata, disamping berfungsi sebagai wahana penyuluhan dan penggerak kegiatan anggotanya. Beberapa kelompok tani juga mempunyai kegiatan lain, seperti gotong royong, usaha simpan pinjam dan arisan kerja untuk kegiatan usahatani (Hermanto, 2007).

\section{Rumusan Masalah}

Berdasarkan latar belakang yang telah dikemukakan, maka yang menjadi permasalahan dalam penelitian ini adalah bagaimana kinerja penyuluh pertanian berdasarkan persepsi kelompok tani di Kelurahan Taratara Satu Kecamatan Tomohon Barat Kota Tomohon.

\section{Tujuan Penelitian}

Penelitian ini bertujuan untuk mengetahui kinerja penyuluh pertanian berdasarkan persepsi Kelompok Tani di Kelurahan Taratara Satu Kecamatan Tomohon Barat Kota Tomohon.

\section{Manfaat Penelitian}

1. Bagi pemerintah sebagai bahan masukan sehingga dapat meningkatkan kualitas Fungsi kerja penyuluh untuk mencapai program kerja yang baik.

2. Bagi peneliti lain, dapat dijadikan referensi kajian dalam penelitian yang sama.

3. Bagi peneliti, sebagai sumber pengetahuan dan informasi mengenai kinerja penyuluh di Kelurahan Taratara Satu kecamatan Tomohon Barat Kota Tomohon.

\section{METODE PENELITIAN}

\section{Waktu dan Tempat Penelitian}

Penelitian ini dilaksanakan selama 3 bulan, dari bulan Febuari sampai dengan bulan April 2020, mulai dari persiapan, pengambilan data sampai dengan penyusunan hasil penelitian. Tempat penelitian dilaksanakan di Kelurahan Taratara Satu Kecamatan Tomohon Barat Kota Tomohon. 


\section{Metode Pengumpulan Data}

Data yang akan digunakan dalam penelitian ini adalah data primer dan data sekunder. Data primer diperoleh dari wawancara langsung, berdasarkan kuesioner yang disediakan peneliti, kepada pengurus dan anggota kelompok tani yang menjadi sampel. Data sekunder diperoleh dari instansi-instansi terkait, antara lain, Badan Pertanian, Perikanan, Perkebunan dan Kehutanan (BP3K) di Kecamatan Tomohon Barat.

\section{Metode Pengumpulan Sampel}

Pengambilan sampel pada penelitian ini menggunakan metode secara sengaja (purposive sampling) dengan mempertimbangkan kriteria yang sesuai dengan tujuan penelitian. Responden yang menjadi sampel adalah pengurus kelompok tani yaitu ketua, sekretaris, bendahara dan anggota. Jumlah responden di setiap kelompok tani 4-5 orang per kelompok. Jumlah keseluruhan responden sebanyak 18 responden yang berasal 4 kelompok tani di Kelurahan Taratara Satu.

\section{Konsep Pengukuran Variabel}

Variabel-variabel yang diukur dalam penelitian ini adalah

A. Identitas Responden

1. Umur (Tahun)

2. Jenis Kelamin (laki-laki, Perempuan)

3. Tingkat Pendidikan, (SD, SMP, SMA, Perguruan Tinggi)

4. Pengalaman Bertani, (Tahun)

5. Status dan Kepemilikan Lahan, (Sewa atau milik sendiri)

6. Keaktifan dalam kegiatan penyuluhan

B. Variabel Pokok

Variabel pokok yang diukur dalam penelitian ini berdasarkan pada Undang-Undang RI No. 16 tentang Sistem Penyuluhan Pertanian, Perikanan, dan Kehutanan. Penjelasan tentang fungsi sistem penyuluhan (Anonim).

\section{Metode Analisis Data}

Rangkuti (2006) mengemukakan bahwa beberapa pendekatan umum yang biasa digunakan dalam pengukuran analisis kinerja penyuluh salah satunya adalah analisis secara deskriptif dimana data yang diperoleh di lapangan kemudian dioalah dan dianalisis secara deskriptif kemudian disajikan dalam bentuk tulisan dan tabel.

\section{HASIL DAN PEMBAHASAN}

\section{Deskripsi Umum Lokasi Penelitian}

Kota Tomohon adalah salah satu kota di Provinsi Sulawesi Utara dengan luas 147,21 Km² Penelitian ini dilaksanakan di Kelurahan Taratara Satu yang merupakan satu kelurahan yang ada di Kecamatan Tomohon Barat, Kota Tomohon.

Kelurahan Taratara Satu memiliki jarak 5 $\mathrm{km}$ dengan ibukota kecamatan, jarak $8 \mathrm{~km}$ dengan ibu kota kabupaten/kota, dan jarak $25 \mathrm{~km}$ dengan ibu kota provinsi. Batas wilayah administrasi Kelurahan Taratara Satu, (Kantor Kelurahan Taratara Satu 2018), sebagai berikut :

Sebelah Utara : Taratara Dua

Sebelah Timur : Taratara Dua dan Woloan Tiga

Sebelah Selatan : Tincep dan Pinaras

Sebelah Barat : Taratara dan Ranotongkor

Kelurahan Taratara Satu berada di ketinggian 400 meter diatas permukaan laut (mdpl) dengan luas wilayah $442.5 \mathrm{Ha}$ yang terdiri dari 8 lingkungan yang meliputi:

Pemukiman : 15 ha

Lahan sawah : 200 ha

Lahan perkebunan : 125 ha

Lahan perkarangan : 2,50 ha

Hutan : 100 ha

Keadaan topografi Kelurahan Taratara Satu berdataran rendah, berkawasan sawah dan dilalui oleh aliran sungai. Kondisi iklim sejuk. Kelembapan udara sekitar 75\% (persen) dan suhu rata-rata $25-35^{\circ} \mathrm{C}$.

\section{Karakteristik Responden}

Karakteristik responden yang menjadi sampel adalah pengurus kelompok tani yaitu ketua, sekretaris, bendahara dan anggota yang ada di setiap kelompok tani jumlah responden 45 orang per kelompok. Jumlah keseluruhan responden sebanyak 18 responden yang berasal 4 kelompok tani di Kelurahan Taratara Satu. Karakteristik responden dapat dilihat pada Tabel 1.

\begin{tabular}{lllll}
\multicolumn{6}{l}{ Tabel 1. Kelompok Tani Padi Sawah Responden } \\
\hline No & Nama kelompok Jumlah & $\begin{array}{c}\text { Tahun } \\
\text { anggota }\end{array}$ & $\begin{array}{c}\text { Kelas } \\
\text { pembentukan }\end{array}$ & Kelompok \\
\hline 1 & Imanuel & 25 & 2005 & Madya \\
2 & Maju Bersama & 15 & 2006 & Madya \\
3 & Aga Kaitombal & 18 & 2009 & Lanjut \\
4 & Amian & 20 & 2010 & Lanjut \\
\hline \multicolumn{4}{l}{ Sumber : Kantor balai penyuluhan Kec, Tomohon Barat, 2020 }
\end{tabular}




\section{Karakteristik Responden Berdasarkan Usia}

Usia merupakan salah satu faktor yang mempengaruhi cara berpikir seseorang, kemampuan dalam bekerja, atau melakukan aktivitas. Petani yang memiliki umur yang lebih muda memiliki kondisi fisik lebih kuat dari pada petani yang berumur lebih tua. responden berdasarkan umur dapat dilihat pada Tabel 2 .

Tabel 2. Distribusi Responden Berdasarkan Usia

\begin{tabular}{llcr}
\hline No & Usia & Jumlah (Petani) & Persentase (\%) \\
\hline 1 & $\leq 40$ & 1 & 6 \\
2 & $41-50$ & 5 & 27 \\
3 & $51-60$ & 8 & 45 \\
4 & $61-70$ & 4 & 22 \\
\hline & Jumlah & 18 & 100 \\
\hline
\end{tabular}

Sumber : Diolah dari data primer, 2020

Tabel 2 menunjukkan bahwa umur petani responden termuda umur 38 tahun sedangkan tertua umur 70 tahun dengan persentase tertinggi responden pada kisaran usia 51 - 60 tahun $(45 \%)$ dan terendah responden pada usia tahun $\leq 40$ tahun $(6 \%)$ responden.

\section{Karakteristik Responden Berdasarkan Jenis Kelamin}

Jenis kelamin merupakan dalah satu faktor penentu dalam bekerja. Laki-laki pada umumnya memiliki kemampuan fisik lebih kuat dibandingkan perempuan. Responden berdasarkan jenis kelamin dapat dilihat pada Tabel 3.

Tabel 3. Distribusi Responden Berdasarkan Jenis Kelamin

\begin{tabular}{llcr}
\hline No & Jenis Kelamin & Jumlah (Petani) & Persentase (\%) \\
\hline 1 & Laki-laki & 17 & 94 \\
2 & Perempuan & 1 & 6 \\
\hline & Jumlah & 18 & 100 \\
\hline
\end{tabular}

Sumber : Diolah dari data primer, 2020

Tabel 3 menunjukkan bahwa jumlah petani responden berjenis kelamin laki-laki lebih banyak 17 orang (94\%), dibandingkan responden yang berjenis kelamin perempuan 1 orang $(6 \%)$.

\section{Karakteristik Responden Berdasarkan Tingkat Pendidikan}

Pendidikan sangat penting bagi petani untuk meningkatkan kualitas dalam cara berpikir maupun dalam pengambilan keputusan. Distribusi pendidikan responden dapat dilihat pada Tabel 4.
Tabel 4. Distribusi Responden Berdasarkan Tingkat Pendidikan

\begin{tabular}{llcr}
\hline No & Pendidikan & Jumlah (Petani) & Persentase (\%) \\
\hline 1 & Sekolah Dasar & 2 & 11 \\
2 & SLTP/SMP & 6 & 33 \\
3 & SLTA/SMA & 9 & 50 \\
4 & Perguruan Tinggi & 1 & 6 \\
\hline \multicolumn{2}{c}{ Jumlah } & 18 & 100 \\
\hline Sumber : Diolah dari data primer, 2020
\end{tabular}

Sumber : Diolah dari data primer, 2020

Tabel 4 menunjukkan distribusi responden berdasarkan tingkat pendidikan terbanyak pada tingkat SLTA/SMA berjumlah 9 orang $(50 \%)$ responden, dan terendah ada pada tingkat Perguruan Tinggi berjumlah 1 orang $(6 \%)$.

\section{Karakteristik Responden Berdasarkan Pengalaman Bertani}

Semakin lama seorang petani bertani, maka semakin luas pengetahuan petani dalam meresponi masalah yang terjadi di lapangan pertanian dan semakin luas pula wawasan petani dalam meningkatkan produktifitas bekerjanya. Distribusi responden berdasarkan pengalaman dapat dilihat pada Tabel 5.

Tabel 5. Distribusi Responden Berdasarkan Pengalaman Bertani

\begin{tabular}{cccr}
\hline No & $\begin{array}{c}\text { Pengalaman } \\
\text { Bertani (Tahun) }\end{array}$ & Jumlah (Petani) & $\begin{array}{r}\text { Persentase } \\
(\%)\end{array}$ \\
\hline 1 & $>15$ & 1 & 5 \\
2 & $16-30$ & 11 & 61 \\
3 & $31-40$ & 4 & 23 \\
4 & $>41$ & 2 & 11 \\
\hline & Jumlah & 18 & 100 \\
\hline
\end{tabular}

Sumber : Diolah dari data primer, 2020

Tabel 5 menunjukkan bahwa petani responden memiliki pengalaman kerja budidaya padi sawah dengan waktu yang berbeda-beda. Distribusi responden berdasarkan pengalaman bertani yang terbanyak pada usia 16-30 tahun 11 petani $(61 \%)$ dan tersedikit kurang dari 15 tahun 1 orang (5\%). Kegiatan bertani paling lama ialah 55 tahun sedangkan pengalaman bertani responden yang paling baru adalah kurang dari 15 tahun.

\section{Karakteristik Responden Berdasarkan Status Penguasaan Lahan}

Tabel 6 menunjukkan bahwa distribusi responden berdasarkan status kepemilikan lahan tertinggi ialah petani pengarap dengan jumlah 9 orang $(50 \%)$ dan terendah pada petani berstatus sebagai pemilik berjumlah 1 orang $(5 \%)$. 
Tabel 6. Distribusi Responden Berdasarkan Status Penguasaan Lahan

\begin{tabular}{llcr}
\hline No & Penguasaan lahan & $\begin{array}{c}\text { Jumlah } \\
\text { (Petani) }\end{array}$ & Persentase (\%) \\
\hline 1 & Pemilik & 1 & 5 \\
2 & Penggarap & 9 & 50 \\
3 & Pemilik dan & 8 & 45 \\
& Penggarap & & \\
\hline & Jumlah & 18 & 100 \\
\hline
\end{tabular}

Sumber : Diolah dari data primer, 2020

\section{Karakteristik Responden Berdasarkan \\ Keaktifan dalam Kegiatan Penyuluhan}

Tabel 7 menunjukkan bahwa distribusi responden berdasarkan aktif tidaknya seorang petani dalam mengikuti kegiatan penyuluhan. Seluruh petani sudah terlibat dan aktif dalam kegiatan penyuluhan dengan jumlah 18 orang dengan persentase $100 \%$.

Tabel 7. Distribusi Responden Berdasarkan Keaktifan dalam Kegiatan Penyuluhan

\begin{tabular}{lccr}
\hline No & $\begin{array}{c}\text { Keaktifan dalam } \\
\text { Kegiatan Penyuluhan }\end{array}$ & $\begin{array}{c}\text { Jumlah } \\
\text { (Petani) }\end{array}$ & $\begin{array}{r}\text { Persentase } \\
(\%)\end{array}$ \\
\hline 1 & Pemilik & 18 & 100 \\
\hline & Jumlah & 18 & 100 \\
\hline
\end{tabular}

Sumber : Diolah dari data primer, 2020

\section{Persepsi Petani Terhadap Kinerja Penyuluh Pertanian}

Persepsi adalah cara pandang seseorang terhadap apa yang dilihat, dirasakan dan didengar, Setiap manusia tentunya memiliki sebuah persepsi terhadap seseorang atau terhadap suatu hal.

Kinerja seorang petani dapat terlaksana dengan baik jika ada komunikasi yang baik antara petani maupun penyuluh untuk mencapai produktifitas usaha tani dengan maksimal.

\section{Memfasilitas Proses Pembelajaran Kelompok Tani}

Tabel 8 menunjukkan bahwa fungsi penyuluh untuk memfasilitasi kelompok Tani upaya terlaksananya proses penyuluhan di kelurahan Taratara Satu, sebanyak 13 responden (72\%) menyatakan bahwa penyuluh memfasilitasi dan membantu menyediakan kebutuhan petani dalam terlaksananya kegiatan penyuluhan sedangkan 5 responden (28\%) lainnya menyatakan penyuluh tidak pernah memfasilitasi petani.
Tabel 8. Fungsi Penyuluh untuk Memfasilitasi Proses Pembelajaran Kelompok Tani

\begin{tabular}{|c|c|c|c|}
\hline No & Petani & YA/TIDAK & Persepsi Petani \\
\hline 1 & WG & YA & $\begin{array}{l}\text { Ya, Memfasilitasi proses pe- } \\
\text { nyuluhan dan menyediakan } \\
\text { tempat agar bisa terjadinya } \\
\text { penyuluhan }\end{array}$ \\
\hline 2 & HW & YA & $\begin{array}{l}\text { Ada memfasilitasi seperti } \\
\text { tempat dan materi yang di } \\
\text { berikan lengkap. }\end{array}$ \\
\hline 3 & DS & YA & $\begin{array}{l}\text { Iya membantu dalam } \\
\text { proses penyuluhan, tetapi } \\
\text { kalau hanya sesama petani, } \\
\text { petani yang menyediakan } \\
\text { tempat, kalau penyuluhan } \\
\text { dari dinas provinsi } \\
\text { penyuluh yang menyedia- } \\
\text { kan fasilitasnya. }\end{array}$ \\
\hline 4 & $\mathrm{BL}$ & YA & $\begin{array}{l}\text { Ya, penyuluh membantu } \\
\text { memfasilitasi dan me- } \\
\text { nyediakan kebutuhan }\end{array}$ \\
\hline 5 & DR & TIDAK & Tidak terealisasi \\
\hline 6 & WP & YA & $\begin{array}{l}\text { Ada tetap memfasilitasi } \\
\text { agar lebih baik lagi. }\end{array}$ \\
\hline 7 & MK & YA & $\begin{array}{l}\text { Memberikan waktu untuk } \\
\text { terlaksananya penyuluhan } \\
\text { namun, kalau untuk kesedian } \\
\text { tempat petani yang sediakan. }\end{array}$ \\
\hline 8 & ST & TIDAK & $\begin{array}{l}\text { Kurang membantu dalam } \\
\text { pelaksanan }\end{array}$ \\
\hline 9 & JS & YA & $\begin{array}{l}\text { Membantu menyediakan } \\
\text { sesuai permintaan petani }\end{array}$ \\
\hline 10 & YS & YA & Ada membantu. \\
\hline 11 & JS & TIDAK & Tidak pernah memfasilitasi \\
\hline 12 & $\mathrm{RR}$ & YA & $\begin{array}{l}\text { Penyuluh yang sediakan } \\
\text { tempatnya }\end{array}$ \\
\hline 13 & HR & YA & $\begin{array}{l}\text { Ya, membantu mem- } \\
\text { fasilitasi seringkali di buat di } \\
\text { persawahan petani. }\end{array}$ \\
\hline 14 & FL & YA & $\begin{array}{l}\text { Iya memfasilitasi, terkadang } \\
\text { langsung di lapangan }\end{array}$ \\
\hline 15 & YE & TIDAK & $\begin{array}{l}\text { Kurang membantu dalam } \\
\text { pelaksanan }\end{array}$ \\
\hline 16 & DS & TIDAK & $\begin{array}{l}\text { Tidak, karena sudah lama } \\
\text { sekali tidak diadakan } \\
\text { penyuluhan. }\end{array}$ \\
\hline 17 & $\mathrm{AD}$ & YA & $\begin{array}{l}\text { Ya, penyuluh membantu } \\
\text { memfasilitasi dan me- } \\
\text { nyediakan kebutuhan. }\end{array}$ \\
\hline 18 & YK & YA & $\begin{array}{l}\text { Ya, kalau tingkat kota } \\
\text { mereka yang memfasilitasi. }\end{array}$ \\
\hline
\end{tabular}

Mengupayakan Kemudahan Akses kelompok

Tani ke Sumber Informasi, Teknologi, dan

Sumberdaya Untuk Mengembangkan Usaha

Tabel 9 menunjukkan bahwa fungsi penyuluh dalam upaya memberikan informasi bagi kelompok tani, sebanyak 14 responden (78\%) menyatakan penyuluh memberikan ide-ide agar petani lebih terampil dalam usaha tani, sedangkan 4 responden $(22 \%)$ menyatakan penyuluh belum memberikan ide-ide karena penyuluh belum pernah turun langsung di lapangan. 
Tabel 9. Fungsi Penyuluh untuk Meningkatkan Kemampuan, Kepemimpinan, dan Kewirausahan Kelompok Tani

\begin{tabular}{|c|c|c|c|}
\hline No & Petani & YA/TIDAK & Persepsi Petani \\
\hline 1 & WG & YA & $\begin{array}{l}\text { Mendorong agar usahatan } \\
\text { lebih baik dan meningkat. }\end{array}$ \\
\hline 2 & HW & YA & $\begin{array}{l}\text { Tetap memberikan } \\
\text { dorongan, tetapi kadang } \\
\text { kalah hanya kalau ada dinas } \\
\text { yang akan turun baru } \\
\text { bergerak. }\end{array}$ \\
\hline 3 & DS & YA & $\begin{array}{l}\text { Iya, tetap memberikan } \\
\text { dorongan kepada petani dan } \\
\text { selalu memberikan motivasi. }\end{array}$ \\
\hline 4 & BL & YA & $\begin{array}{l}\text { Mendoromg petani karena itu } \\
\text { tugas mereka. }\end{array}$ \\
\hline 5 & DR & YA & $\begin{array}{l}\text { mendorong tetapi tidak dapat } \\
\text { membantu secara langsung. }\end{array}$ \\
\hline 6 & WP & TIDAK & $\begin{array}{l}\text { Kurang aktif, hanya melihat } \\
\text { tapi kurang di lakukan }\end{array}$ \\
\hline 7 & MK & YA & $\begin{array}{l}\text { Ya penyuluh mendorong dan } \\
\text { memotivasi petani karena itu } \\
\text { tugas mereka. }\end{array}$ \\
\hline 8 & ST & TIDAK & $\begin{array}{l}\text { belum pernah mendorong } \\
\text { kususnya saya pribadi }\end{array}$ \\
\hline 9 & JS & YA & $\begin{array}{l}\text { pernah tetapi tidak selalu } \\
\text { melakukan }\end{array}$ \\
\hline 10 & YS & YA & $\begin{array}{l}\text { Ya tetap memberikan } \\
\text { dorongan kepetani }\end{array}$ \\
\hline 11 & JS & YA & $\begin{array}{l}\text { pernah memotivasi petani } \\
\text { tetapi sudah lama }\end{array}$ \\
\hline 12 & RR & YA & $\begin{array}{l}\text { Ya sering penyuluh itu } \\
\text { mendorong. }\end{array}$ \\
\hline 13 & HR & YA & $\begin{array}{l}\text { Ya penyuluh membantu usaha } \\
\text { tani }\end{array}$ \\
\hline 14 & FL & YA & $\begin{array}{l}\text { Ya pernah menolong petani } \\
\text { dalam bentuk bantuan dari } \\
\text { dinas }\end{array}$ \\
\hline 15 & YE & TIDAK & $\begin{array}{l}\text { Belum pernah memotivasi } \\
\text { kususnya di saya }\end{array}$ \\
\hline 16 & DS & TIDAK & $\begin{array}{l}\text { Tidak karena yang } \\
\text { mendapatkan penyuluhan } \\
\text { seringkali hanya pengurus } \\
\text { kelompok saja }\end{array}$ \\
\hline 17 & $\mathrm{AD}$ & YA & Ya mendorong petani. \\
\hline 18 & YK & YA & $\begin{array}{l}\text { Ya mendorong } \\
\text { memberikan informasi }\end{array}$ \\
\hline
\end{tabular}

Sumber : Diolah dari data Primer, 2020

Membantu Dalam Menumbuh Kembangkan Organisasi (usaha tani) Yang Berdaya Saing Tinggi, Produktifitas, dan Tata Kelola Yang Baik Dan Berkelanjutan

Tabel 10 menunjukkan bahwa fungsi penyuluh untuk menghubungkan dan membantu serta menumbuh kembangkan usahatani, sebanyak 15 responden (83\%) menyatakan bahwa penyuluh menjadi perantara kelompok tani ke dinas agar mendapatkan bantuan-bantuan berupa pupuk, bibit, racun serta alat-alat pertanian melalui proposal yang di buat. Sedangkan 3 responden (17\%) lainya menyatakan bahwa penyuluh tidak pernah membantu petani dan bantuan-bantuan yang ada tidak pernah didapat.
Tabel 10. Fungsi Penyuluh Sebagai Penguhubung dalam Upaya untuk Membantu Menumbuh Kembangkan Usahatani dan Berdaya Saing Tinggi

\begin{tabular}{|c|c|c|c|}
\hline No & Petani Responden & YA/TIDAK & Persepsi Petani \\
\hline 1 & WG & YA & $\begin{array}{l}\text { Ya penyuluh menfasilitasi } \\
\text { sampai kesejathran petani } \\
\text { dalam kelompok. }\end{array}$ \\
\hline 2 & HW & YA & $\begin{array}{l}\text { Tetap ada dan menjadi } \\
\text { perantara antara kelompok. }\end{array}$ \\
\hline 3 & DS & YA & $\begin{array}{l}\text { Ya mereka memberikan } \\
\text { informasi mengenai bantuan } \\
\text { melalui proposal agar dapat } \\
\text { bantuan. }\end{array}$ \\
\hline 4 & BL & YA & $\begin{array}{l}\text { Ya, kebanyakan melalui } \\
\text { penyuluh bantuan" yang di } \\
\text { dapat. }\end{array}$ \\
\hline 5 & $\mathrm{DR}$ & TIDAK & Belum tau \\
\hline 6 & WP & YA & $\begin{array}{ll}\text { Ya } & \text { mereka } \\
\text { menginformasikan } & \text { dengan } \\
\text { proposal } & \end{array}$ \\
\hline 7 & MK & YA & $\begin{array}{l}\text { Ya menjadi perantara antara } \\
\text { dinas dan instansi terkait. } \\
\text { Contoh dengan memberikan } \\
\text { informasi tentang bantuan- } \\
\text { bantuan }\end{array}$ \\
\hline 8 & ST & TIDAK & $\begin{array}{l}\text { Hanya memberikan } \\
\text { informasi mengenai bantuan } \\
\text { pupuk dan lain-lain. }\end{array}$ \\
\hline 9 & JS & YA & $\begin{array}{l}\text { Pernah, membantu membuat } \\
\text { proposal bantuan yang dari } \\
\text { pemerintah. }\end{array}$ \\
\hline 10 & YS & YA & $\begin{array}{l}\text { Seringkali langsung dari } \\
\text { petani kepenyuluh dan } \\
\text { pemerintah }\end{array}$ \\
\hline 11 & JS & YA & $\begin{array}{llr}\text { Pernah dan } & \text { selalu } \\
\text { berhubungan } & \text { baik } & \text { dengan } \\
\text { petani. } & & \end{array}$ \\
\hline 12 & $\mathrm{RR}$ & YA & $\begin{array}{l}\text { Ya, memberikan informasi } \\
\text { bantuan-bantuan pupuk alat- } \\
\text { alat dan obat-obatan. }\end{array}$ \\
\hline 13 & $\mathrm{HR}$ & YA & $\begin{array}{l}\text { Ya sering penyuluh yang } \\
\text { memberikan informasi }\end{array}$ \\
\hline 14 & FL & YA & $\begin{array}{l}\text { Ya penyuluh membantu } \\
\text { perantara dari kelompok tani } \\
\text { ke dinas }\end{array}$ \\
\hline 15 & YE & YA & $\begin{array}{l}\text { Ya memberikan informasi } \\
\text { mengenai bantuan pupuk dan } \\
\text { lain-lain. }\end{array}$ \\
\hline 16 & DS & TIDAK & $\begin{array}{l}\text { Tidak, karena seringkali } \\
\text { penyuluh hanya ketemu } \\
\text { dengan ketua kelompok saja } \\
\text { dan tidak di teruskan oleh } \\
\text { ketua kelompok }\end{array}$ \\
\hline 17 & $\mathrm{AD}$ & YA & $\begin{array}{l}\text { Ya, kebanyakan melalui } \\
\text { penyuluh bantuan-bantuan } \\
\text { yang di dapat. }\end{array}$ \\
\hline 18 & YK & YA & $\begin{array}{l}\text { Ya menjadi penghubung } \\
\text { dengan petani }\end{array}$ \\
\hline
\end{tabular}

Sumber : Diolah dari data Primer, 2020

\section{Membantu Mengalisis dan Memecahkan Masalah serta Merespon Peluang dan Tantangan yang Dihadapi dalam Mengelola Usaha Tani}

Tabel 11 menunjukkan bahwa fungsi penyuluh untuk membantu memecahkan masalah serta memberikan solusi bagi petani, sebanyak 13 responden $(72 \%)$ menyatakan bahwa penyuluh membantuh petani dalam memecahkan masalah 
yang ada di lapangan serta memberikan solusi kepada petani berupa cara menangulangi hama, serta obat dan racun apa yang harus di pakai sehingga petani memahami apa yang harus dilakukan, sedangkan 5 responden (28\%) menyatakan penyuluh tidak pernah datang ke lokasi persawahan dan melihat langsung masalah yang dihadapi petani dan kurangnya perhatian dari dinas terkait dan seringkali hanya petani saja yang mencari solusinya sendiri.

\begin{tabular}{|c|c|c|c|}
\hline & 1. $\begin{array}{l}\mathrm{Fu} \\
\mathrm{M} \\
\mathrm{M}\end{array}$ & $\begin{array}{l}\text { Ingsi Pe } \\
\text { emecahka } \\
\text { emberikar }\end{array}$ & $\begin{array}{llr}\text { nyuluh } & \text { untuk } & \text { Membantu } \\
\text { n } & \text { Masalah } & \text { Serta } \\
\text { n Solusi bagi Kelompok Tani }\end{array}$ \\
\hline No & $\begin{array}{c}\text { Petani } \\
\text { Responden }\end{array}$ & $\begin{array}{c}\text { Ya/ } \\
\text { Tidak }\end{array}$ & Persepsi Petani \\
\hline 1 & WG & YA & $\begin{array}{l}\text { Ya membantu petani dalam } \\
\text { penangulangi masalah } \\
\text { misalnya, hama dam racun } \\
\text { yang akan di pakai dan lainya } \\
\text { juga }\end{array}$ \\
\hline 2 & HW & TIDAK & $\begin{array}{l}\text { Seringkali petani yang cari } \\
\text { sendiri dan solusi cari sendiri. }\end{array}$ \\
\hline 3 & DS & YA & $\begin{array}{l}\text { Ya, membantu setiap masalah } \\
\text { yang di hadapi dan turun } \\
\text { langsung kelapangan melihat } \\
\text { masalah yang ada. }\end{array}$ \\
\hline 4 & BL & YA & $\begin{array}{l}\text { Ya pernah memecahkan } \\
\text { masalah dan mencari solusi }\end{array}$ \\
\hline 5 & DR & TIDAK & $\begin{array}{l}\text { Tidak pernah datang dan tidak } \\
\text { pernah memecahkan masalah. }\end{array}$ \\
\hline 6 & WP & YA & $\begin{array}{l}\text { Pernah. Memecahkan masalah } \\
\text { dan mencari solusi }\end{array}$ \\
\hline 7 & MK & YA & $\begin{array}{l}\text { Ya datang melihat dan } \\
\text { memberikan solusi dang turun } \\
\text { langsung juga pernah }\end{array}$ \\
\hline 8 & ST & TIDAK & $\begin{array}{l}\text { Hanya pernah mereka } \\
\text { memberikan pengharaan tetapi } \\
\text { sudah lama sekali. }\end{array}$ \\
\hline 9 & JS & YA & $\begin{array}{l}\text { Masih kurang dalam perubahan } \\
\text { secara berkelanjutan }\end{array}$ \\
\hline 10 & YS & YA & $\begin{array}{l}\text { Ya ada pernah langsung turun } \\
\text { dan lihat langsung kelapangan. }\end{array}$ \\
\hline 11 & JS & TIDAK & Tidak pernah memfasilitasi \\
\hline 12 & RR & YA & $\begin{array}{l}\text { Ya pernah tetapi tidak rutin di } \\
\text { lakukan. }\end{array}$ \\
\hline 13 & HR & YA & $\begin{array}{l}\text { Ya. Penyuluh tetap turun } \\
\text { langsung dan } \\
\text { memberikan solusi. }\end{array}$ \\
\hline 14 & FL & YA & $\begin{array}{l}\text { Pernah memecahakan masalah } \\
\text { memberikan obat dan racun, } \\
\text { dan memberikan masukan. }\end{array}$ \\
\hline 15 & YE & YA & $\begin{array}{l}\text { Hanya pernah mereka } \\
\text { memberikan pengharaan tetapi } \\
\text { sudah lama sekali. }\end{array}$ \\
\hline 16 & DS & TIDAK & $\begin{array}{l}\text { Kurang soalnya kalau turun } \\
\text { langsung di lokasi saya belum } \\
\text { pernah. }\end{array}$ \\
\hline 17 & $\mathrm{AD}$ & YA & $\begin{array}{l}\text { Ya pernah memecahkan } \\
\text { masalah dan mencari solusi. }\end{array}$ \\
\hline 18 & YK & YA & $\begin{array}{l}\text { Ya pernah datang dan } \\
\text { memberikan solusi. }\end{array}$ \\
\hline
\end{tabular}

\section{Menumbuhkan Kesadaran Bagi Kelompok Tani dalam Meningkatkan Kelestarian Fungsi Lingkungan}

Tabel 12 menunjukkan bahwa fungsi penyuluh dalam upaya menumbuhkan kesadaran bagi petani dalam meningkatkan fungsi lingkungan, sebanyak 12 responden (67\%) menyatakan bahwa penyuluh berperan aktif dalam upaya membimbing dan memotivasi petani agar lebih baik lagi, penyuluh mengarahkan petani agar dapat mendapatkan hasil produksi yang lebih baik dengan menerapkan sistem tanam jajar legowo sehingga di harapkan hasil yang di dapat lebih baik. sedangkan 6 responden $(33 \%)$ menyatakan bahwa penyuluh tidak berperan aktif dalam membimbing petani karena dalam praktek langsung penyuluh kurang untuk turun langsung di lapangan dan berinteraksi dengan petani, sehingga selama ini petani kurang mendapatkan bimbingan dari penyuluh.

Tabel 12. Fungsi Penyuluh untuk Menumbuhkan Kesadaran bagi Petani dalam Meningkatkan Fungsi Lingkungan

\begin{tabular}{|c|c|c|c|}
\hline No & $\begin{array}{c}\text { Petani } \\
\text { Responden }\end{array}$ & $\begin{array}{c}\text { Ya/ } \\
\text { Tidak }\end{array}$ & Persepsi Petani \\
\hline 1 & WG & YA & $\begin{array}{l}\text { Ya penyuluh mendorong petani agar } \\
\text { lebih baik. }\end{array}$ \\
\hline 2 & HW & YA & $\begin{array}{l}\text { IYA, penyuluh orang pertamah } \\
\text { yang memberikan informasi. }\end{array}$ \\
\hline 3 & DS & YA & $\begin{array}{l}\text { Ya penyuluh memberikan arahan } \\
\text { dan motivasi agar terjadi perubahan. }\end{array}$ \\
\hline 4 & BL & YA & $\begin{array}{l}\text { Ya mengarahkan kearah yang lebih } \\
\text { baik. }\end{array}$ \\
\hline 5 & DR & TIDAK & $\begin{array}{l}\text { Tidak juga karena selama ini tidak } \\
\text { pernah dapat motivasi dari } \\
\text { punyuluh }\end{array}$ \\
\hline 6 & WP & YA & $\begin{array}{l}\text { Ya, mengupayakan dan memotivasi } \\
\text { petani }\end{array}$ \\
\hline 7 & MK & YA & $\begin{array}{l}\text { Ya supaya lebih untung dan lebih } \\
\text { banyak hasil, contonya dengan sistem }\end{array}$ \\
\hline 7 & MK & YA & $\begin{array}{l}\text { tanam legowo yg lebih } \\
\text { menguntungkan. }\end{array}$ \\
\hline 8 & ST & TIDAK & $\begin{array}{l}\text { Tidak, tidak pernah muncul di } \\
\text { lapangan. }\end{array}$ \\
\hline 9 & JS & TIDAK & Belum pernah menganjurkan \\
\hline 10 & YS & TIDAK & $\begin{array}{l}\text { Kurang disiplin karena kalau turun } \\
\text { langsung kepetani sangat kurang. }\end{array}$ \\
\hline 11 & JS & YA & $\begin{array}{l}\text { Ya, contohnya pernah memberikaan } \\
\text { bantuan kepetani dalam upaya } \\
\text { mengembangkan usaha tani }\end{array}$ \\
\hline 12 & RR & YA & Pernah tetapi kurang \\
\hline 13 & HR & YA & $\begin{array}{l}\text { Ya, contoh memberikan cara tanam } \\
\text { legowo sehingga hasil lebih baik. }\end{array}$ \\
\hline 14 & FL & YA & $\begin{array}{l}\text { Ya tetap memotivasi,dan pernah } \\
\text { menganjurkan untuk menanam secara } \\
\text { legowo agar hasil lebih baik. }\end{array}$ \\
\hline 15 & YE & YA & $\begin{array}{l}\text { Ya mendorong petani lebih maju dan } \\
\text { lebih baik lagi kedepanya }\end{array}$ \\
\hline 16 & DS & TIDAK & $\begin{array}{l}\text { Belum pernah karena selama ini } \\
\text { kurang turun lapangan }\end{array}$ \\
\hline 17 & $\mathrm{AD}$ & TIDAK & $\begin{array}{l}\text { Tidak karena penyuluh kurang } \\
\text { berinterasi dengan petani khususnya } \\
\text { saya. }\end{array}$ \\
\hline 18 & YK & YA & $\begin{array}{l}\text { Ya menjadi pemicu karena itu tugas } \\
\text { mereka. }\end{array}$ \\
\hline
\end{tabular}




\section{Melembagakan Nilai-Nilai Budaya Pembangunan Pertanian, Perikanan dan Kehutanan yang Maju dan Modern Secara Berkelanjutan bagi Kelompok Tani}

Tabel 13 menunjukkan bahwa fungsi penyuluh dalam menanamkan nilai-nilai pembangunan pertanian yang modern secara berkelanjutan,sebanyak 12 responden (67\%) menyatakan bahwa selama ini penyuluh mengarahkan petani agar dapat memakai pupuk organik agar dapat mendapatkan hasil yang lebih baik, petani juga menyampaikan bahwa penyuluh disiplin dalam melaksanakan program penyuluhan dalam membimbing petani juga penyuluh berperan aktif sehingga ada hubungan komunikasi yang baik antara penyuluh dan kelompok tani. sedangkan 6 responden $(33 \%)$ menyatakan bahwa dalam upaya membimbing petani penyuluh kurang disiplin karena untuk berkunjung di lapangan penyuluh kurang berkunjung jika ada hanya ke pengurus kelompok tani saja tidak ke semua petani.

Tabel 13. Fungsi Penyuluh untuk Menanamkan Nilai-Nilai Pembangunan Pertanian yang Modern Secara Berkelanjutan

\begin{tabular}{|c|c|c|c|}
\hline No & $\begin{array}{c}\text { Petani } \\
\text { Responden }\end{array}$ & Ya/Tidak & Persepsi Petani \\
\hline 1 & WG & YA & $\begin{array}{l}\text { Iya. Penyuluh disiplin dalam melaksanakan tugas serta memberikan inovasi tentang } \\
\text { pemakaian pupuk organik agar lebih mendapatkan kualitas yang lebih baik. }\end{array}$ \\
\hline 2 & HW & TIDAK & $\begin{array}{l}\text { Penyuluh kurang disiplin dalam turun langsung di lapangan, kurangnya sekali interaksi } \\
\text { dengan petani. }\end{array}$ \\
\hline 3 & DS & YA & $\begin{array}{l}\text { Disiplin dalam melaksanakan tugas penyuluhan dan memberikan informasi bagaimana } \\
\text { keuntungan jika menggunakan pupuk organic, serta memiliki komunikasi yang baik } \\
\text { dengan petani. }\end{array}$ \\
\hline 4 & BL & YA & $\begin{array}{l}\text { Iya setiap ada program mereka selalu aktif, pernah mereka menganjurkan agar } \\
\text { memakai pupuk yang organik dan melarang memakai pupuk yang peptisida kimia, } \\
\text { mereka selalu ada hubungan yang baik dengan petani. }\end{array}$ \\
\hline 5 & DR & YA & $\begin{array}{l}\text { Penyuluh disiplin tetapi kurang maksimal, selama ini sudah lama sekali tidak di adakan } \\
\text { penyuluhan, dan kurang berinteraksi dengan petani. }\end{array}$ \\
\hline 6 & WP & YA & $\begin{array}{l}\text { Penyuluh disiplin dan tetap ada perhatian kepada petani, selalu penyuluh membimbing } \\
\text { petani dengan mengarahkan petani dan memberikan inovasi agar lebih baik kepada } \\
\text { petani, dan hubungan penyuluh dengan petani baik. }\end{array}$ \\
\hline 7 & MK & YA & $\begin{array}{l}\text { Penyuluh disiplin dan mengarahkan petani serta memberikan masukan yang baik } \\
\text { kepada petani contonya dengan menganjurkan pemakaian pupuk organic dan melarang } \\
\text { memakai pupuk kimia secara terus menerus. }\end{array}$ \\
\hline 8 & ST & YA & $\begin{array}{l}\text { tetap disiplin tetapi belum maksimal dan selama ini dalam membimbing petani tetapi } \\
\text { komunikasi tetap ada. }\end{array}$ \\
\hline 9 & JS & TIDAK & $\begin{array}{l}\text { Penyuluh sekarang ini kurang displin karna jarang untuk turun lapangan,tetapi kalau } \\
\text { komunikasi dengan penyuluh tetap ada tetapi masi kurang untuk turun langsung dan } \\
\text { menyelesaikan masalah yang ada di lapangan. }\end{array}$ \\
\hline 10 & YS & YA & $\begin{array}{l}\text { Ya penyuluh selalu memberikan arahan yang baik dalam usaha tani dan dalam } \\
\text { membudidayakan agar hasil yang akan di dapat itu bagus dan selalu membimbing } \\
\text { petani dan ada komunikasi yang baik dengan petani. }\end{array}$ \\
\hline 11 & JS & TIDAK & $\begin{array}{l}\text { Tidak, ada kalahnya setelah ada kunjungan dari dinas penyuluh langsung } \\
\text { pulang dan kurang interaksi dengan kelompok tani. }\end{array}$ \\
\hline 12 & RR & TIDAK & $\begin{array}{l}\text { kurang disiplin, kalau ada laporan baru turun, kurang aktif. Tetapi tetap ada bimbingan } \\
\text { kepada petani bagaimana memakai pupuk atau alat-alat pertanian yang baik agar } \\
\text { produksi hasilnya meningkat, serta ada komunikasi yang baik. }\end{array}$ \\
\hline 13 & HR & YA & $\begin{array}{l}\text { Tetap ada tetapi terkadang kurang aktif dalam lapangan, pernah memberikan informasi } \\
\text { untuk mendapatkan bantuan pupuk organi tetapi sampai sekarang belum pernah di } \\
\text { salurkan, tetapi masi memliki komunikasi yang baik dengan petani. }\end{array}$ \\
\hline 14 & FL & TIDAK & $\begin{array}{l}\text { Kurang disiplin, untuk mengenai pemakain pupuk belum pernah di sampaikan, } \\
\text { komunikasi juga tidak terlalu baik. }\end{array}$ \\
\hline 15 & YE & TIDAK & $\begin{array}{l}\text { kalau disiplin kurang disiplin karena mungkin mereka hanya berkunjung dan datang } \\
\text { hanya ke petani tertentu atau ke ketua kelompok, }\end{array}$ \\
\hline 16 & DS & YA & $\begin{array}{l}\text { selama ini untuk penyuluhan belum perna ikut } \\
\text { dengan penyuluh langsung. }\end{array}$ \\
\hline 17 & $\mathrm{AD}$ & YA & $\begin{array}{l}\text { Kalau ada program mereka selalu aktif, pernah menganjurkan memakai pupuk yang } \\
\text { organik agar lebih bagus hasil panennya, kalau komunikasi baik. }\end{array}$ \\
\hline 18 & YK & YA & Disiplin karena sering ketemu, ada komunikasi yang baik. \\
\hline
\end{tabular}

Sumber : Diolah dari Data Primer, 2020 


\section{KESIMPULAN DAN SARAN}

\section{Kesimpulan}

Berdasarkan penelitian yang telah dilakukan pada pengurus dan anggota dari empat kelompok tani di Kelurahan Taratara Satu Kecamatan Tomohon Barat Kota Tomohon menyangkut kinerja penyuluh pertanian berdasarkan persepsi mereka dapat di simpulkan bahwa penyuluh sudah menjalankan fungsinya dengan baik, yang tertinggi pada fungsi ke 4 (15 petani atau 83 persen) diikuti dengan fungsi ke 2 dan ke 3 (masing-masing 14 petani atau 78 persen), sedangkan terendah fungsi ke 6 dan 7 (masing-masing 12 petani atau 67 persen). Hal ini dapat dilihat dari sebagian besar responden yang menyatakan bahwa penyuluh telah membimbing dan memfasilitasi petani agar lebih baik lagi.

\section{Saran}

Diharapkan kepada penyuluh serta dinas pertanian agar lebih meningkatkan lagi kegiatan penyuluhan.Diperlukan juga bantuan dari pemerintah agar proses pembimbingan ke petani lebih baik lagi perlu penambahan tenaga kerja penyuluh di setiap Kelurahan agar lebih baik lagi. Penelitian ini juga perlu ditindaklanjuti dengan menanyakan pertanyaan yang sama kepada pimpinan Penyuluh yang ada Kecamatan Tomohon Barat Kota Tomohon.

\section{DAFTAR PUSTAKA}

Animar 2013, Persepsi Petani Padi Terhadap Kinerja Penyuluh Pertanian Di Kecamatan Suka Makmue Kabupaten Nagan Raya. Aceh Barat: Program Studi Agribisnis Fakultas Pertanian Universitas Teuku Umar Meulaboh.
Anonim. Undang-undang Nomor 16 Tahun 2006. Tentang System Penyuluhan Pertanain, Perikanan dan Kehutanan.

Gomes, Faustino Cardoso.(2001). Manajemen Sumber Daya Manusia.Yogyakarta.

Hasan, S. 2016. Pengaruh Penyuluh Pertanian Dalam Aspek Lingkungan, Ekonomi dan Teknologi Pada Padi Sawah Di Kecamatan Modayag, Skripsi. Fakultas Pertanian Universitas Sam Ratulangi.

Hermanto.R.2007, Rencana Kelembagaan Tani Dalam Implementasi Prima Tani Di Sumatera Selatan.

Jahi A., Ani, L.2006, Kinerja Penyuluh Pertanian di Beberapa Kabupaten di Provinsi Jawa Barat.

Mardikanto, T. 2009. Sistem Penyuluhan Pertanian. Diterbitkan atas Kerja sama Lembaga Pengembangan Pendidikan (LPP) dan UPT Penerbitan dan Pencetakan UNS (UNS Press), Universitas Sebelas Maret.

Rangkuti, F. 2006. Measuring Costumer Satisfaction. Gramedia Pustaka Utama, Jakarta.

Slameto, 2010. Pengantar Psikologi Umum. Jakarta: PT Raja Grafindo Persada, Jakarta.

Tinaprilla. N. 2014, Kepuasan Petani Terhadap Kinerja Pelayanan Penynuluh Pertanian di Desa Situ Udik Kecamatan Cibungbulang Kabupaten Bogor Provinsi Jawa Barat. 